\title{
Characteristics and Countermeasures of China's College English Teaching during the Transitional Period
}

\author{
Lin Jing ${ }^{1, a}$, Duan Zhongyu ${ }^{*, 1, b}$ \\ *Correspondence Author \\ ${ }^{1}$ College of International Education, Yunnan University of Traditional Chinese Medicine, Kunming \\ City, Yunnan Province, 650500, China
}

Keywords: Teaching transformation; College English; Teaching characteristics; Countermeasures

\begin{abstract}
The transitional development has become a topic with great concern in universities, especially the local undergraduate ones, which is a significant reform of China's higher education in the 21st century. The unanimous concern in college English field has been attached to issues regarding how college English, one of the important basic courses of higher education, can deal with the reform impact, adapt to the reform needs, and better serve the development goals of universities' construction and transformation. In this paper, based on the author's learning and practical experience, we firstly analyzed the characteristics of college English teaching in China during the transitional period, and then put forward the teaching strategies of college English in China during the transitional period.
\end{abstract}

\section{Introduction}

In March 2014, the Ministry of Education issued the document named "Guideline on the Transformation and Development of Local Undergraduate Universities". According to the guideline, more than half of the universities (More than six hundred) in China will make the transition to vocational education. Prior to this guideline, in 2010, the state promulgated the document named "Guideline on National Medium and Long Term Education Reform and Development Plan (2010-2020)", in which the future development direction of China's education was fully deployed, and higher requirements regarding college English teaching and reform were also raised. The transformation and development of local undergraduate universities will be a major change in the history of higher education in China. College English is a crucial part of the training of professional personnel in universities, and is bound to be subjected to the impact of this change. The common focus of all college English teachers and learners is how the college English teaching will develop, and college English teachers can cope with the opportunities and challenges during the transitional period.

\section{Characteristics of College English Teaching in China during the Transitional Period}

\subsection{Boundaries among college English, high school English and English professional are gradually blurred}

First, the initial levels of non-English majors and English majors in universities, especially the key universities, have been narrowed. Presently, many high-school graduates with outstanding English proficiency are admitted to non-English majors. Second, the English levels of graduates have a narrowed trend. This is because the English study period of non-English majors has been continuously extended. In addition to the basic English in the previous two years, there are also various optional courses and professional English in the last two years. The universities are striving for "four-year uninterrupted line". Many institutions set up the second degree program of English majors for non-English majors. It should be said that English level of non-English majors is close to (even more than) the level of English majors. Third, the curriculum arrangement and examination difficulty of college English and English professional tend to be uniform. The goal of cultivating 
students' comprehensive application ability in college English has been very close to that of linguistic competence of the English majors. Both of the focuses are placed on the base of reading, writing, listening and speaking. In addition to basic English, college English also has elective courses of English majors such as advanced translation, advanced writing, advanced oral, newspaper reading, literature appreciation and linguistics introduction.

\subsection{Basic English teaching of college English is loosening up}

The development of English training in future will focus on English practical communication skills, as well as professional English training based on work needs. For the purpose of choosing the English training institutions, the majority of the interviewees aim at improving their English proficiency and strengthening their own competitiveness, which has a strong relationship with the individual development. In regards to the enterprise's demand for talents, more and more enterprises attach much importance to talents' oral English communication skills, rather than a piece of certificate. This is why, on the one hand, the skipping situation of college English classes is growing, and on the other hand the number of students attending social foreign language training is increasing day by day, which reflects the fact that the universities are less responsive to market demand, and college students are dissatisfactory with the present college English curriculum. It is under this background that China's college English teaching quietly transfers from simple basic language training to practical ability including professional English skills. The main characteristics of the era of post-college English teaching, namely the transitional period, are: the number of semesters and weeks at basic English stage is on the decrease, and the elective courses focusing on cultivating various abilities are on the increase.

\subsection{Standardized uniform teaching is developing towards diversified teaching}

In the era of post-college English teaching, the "chaos" situation regarding credits requirements, curriculum setup, teaching arrangements, examination form, etc appeared in national college English teaching. The CET-4 and CET-6 are no longer a mandatory uniform examination, namely no longer the examination claimed in "examination outline" that "comprehensively evaluates if the identified goals formulated in examination outline were achieved by students who have completed the college English band four". Although many schools still require students to pass the CET-4, more and more schools announced that students' graduation has no relationships with the CET-4, and the students are only required to pass the school curriculum examination. In the aspects of curriculum arrangement, with the promotion of multimedia modern teaching technology, the form is more diverse.

\section{Teaching Strategies of College English in China during the Transitional Period}

From the macroscopic aspects, under the background of the transformation and development of the universities, a single professional graduate with low proficiency in foreign languages can no longer adapt to the rapid development of the national economy and the severe competition in the employment market. College English teaching, an important part of Chinese higher education, must keep on reflection, reform and optimization so as to take up the task of training composite and application-oriented talents. As early as 1996, Liu Runqing pointed out that English for specific purpose (ESP) teaching will become the mainstream of English teaching in the 21st century. ESP teaching is characterized by purposeful use, special language content and satisfaction of individual needs, which meet the needs of social and economic development and the individualized development of English majors.

For the prediction of future English teaching, Graddol (2006) claimed that there will be no longer only one teaching mode, one teaching method, one English textbook, one test method, and even one English for learning. In terms of China' current situation, the gradual establishment of college English curriculum system with the base of English for general purpose (EGP) and the main development direction of English for specific purposes (ESP) will be bound to better meeting the needs of cultivating diversified talents, and being in line with China's actual needs of English education, which 
is China's urgent needs of social, cultural, economic and political development. ESP has a diversified and personalized curriculum design and student-centered curriculum system, and forces students not to learn the same textbook and participate in the same examination, but to establish a teaching system fully meeting the students' needs, which is the mainstream of China' college English teaching.

During the period of college English transformation and development, the development strategies of universities' college English include the following aspects: establish the subject status and demand field of ESP so as to make the college English-related curriculum arrangement more scientific and reasonable, develop and construct follow-up courses of college English so as to meet the different needs of students for the English application, set up and gradually standardize the English elective courses so as to provide career development services for the students, achieve individualized teaching according to different curriculum characteristics and learning resources so as to change the traditional single teaching mode.

From the perspective of students' career development and planning, English, a communication tool, should better realize the practical features of serving the career development in the category of higher education. In the process of setting up teaching objectives, college English teachers should integrate the factors and ideas of vocational education such as occupation, skills and hobbies into the college English teaching objectives so that the students can form their own understanding and conception of vocational needs in the process of learning English language knowledge, which makes college English teaching embody the elements of vocational education. In the process of teaching, we should combine students' vocation and major appropriately with the aid of the relevant knowledge involved in the text, highlight the professional hot vocabulary or topic, organize students to study in groups and complete the career-related course tasks, and develop students' ability to work together and team spirit.

From the perspective of the development of college English teachers, we should be fully prepared for the transformation when the problems such as reduced learning period, decreased credit and the "removing foreign language" increasingly become prominent. Excellent teachers are prerequisite for the success of education. Strengthening the teaching staff construction of college English teacher can be realized from the following two aspects. First, the national education departments and institutions as well as universities should recognize the urgency and importance of the transformation and cultivation of college English teachers, strengthen the training of English for special purpose and modern media technology of college English teachers, and create conditions to strengthen exchanges and learning among domestic and foreign English teachers. Second, from the perspective of college English teachers themselves, they should constantly enhance their understanding of the trend of transformation and development, continuously improve their professional standards and scientific research capabilities, strengthen the sense of innovation, establish teaching research team with the similar or same interests and majors, and realize the successful transformation and sustainable development in the process of reform.

\section{Summary}

A unified rigid education era has ended, and a post-college English era with the emphasis on pluralism and individuality has arrived. Under the background of the transformation and development of the universities, the educators should recognize the crisis, consider the specific situation, reflect on how to adapt to the needs of reform and development and how to promote the smooth transition and sustainable development of college English teaching during the transitional period, fully analyze the existing favorable and unfavorable factors to make up for each other, and take positive actions to train all kinds of talents who meet China' social development needs.

\section{References}

[1] LIU Xiaomin, LIU Jinlong. College English translation teaching: Problems and countermeasures [J]. Shandong Foreign Language Teaching, 2013, (05): 69-73. 
[2] XU Jinfen. Problems and countermeasures of college English teaching in China [J] Contemporary Foreign Languages Research, 2011, (10): 26-31 + 60-61.

[3] MAO Meilan. Research on problems and countermeasures of college English multimedia teaching [J]. Audio-visual Education Reseach, 2010, (02): 68-70.

[4] GUO Shuli, TANG Ya. Analysis on the current situation and countermeasures of artistic college English teaching [J] .Journal of Hebei Radio \& TV University, 2009, (01): 69-71.

[5] LI Zhonghua. College English translation teaching: Current situation and countermeasures [J]. Foreign Language and Foreign Language Teaching, 2007, (09): 47-49.

[6] LI Pengzhou. College English teaching: Problems and countermeasures [J]. Journal of Xiangfan Vocational and Technical College, 2007, (02): 75-78.

[7] LI Xinguo. Embarrassment and countermeasures of art college English teaching [J]. Polytechnic Higher Education Research, 2006, (04): 117-118. 